\title{
On the quantification of security
}

\author{
Sørensen, Bent
}

\section{Publication date:}

1984

\section{Document Version}

Publisher's PDF, also known as Version of record

\section{Citation for published version (APA):}

Sørensen, B. (1984). On the quantification of security. Roskilde Universitet. Tekster fra IMFUFA No. 83 http://milne.ruc.dk/ImfufaTekster/

\section{General rights}

Copyright and moral rights for the publications made accessible in the public portal are retained by the authors and/or other copyright owners and it is a condition of accessing publications that users recognise and abide by the legal requirements associated with these rights.

- Users may download and print one copy of any publication from the public portal for the purpose of private study or research. - You may not further distribute the material or use it for any profit-making activity or commercial gain.

- You may freely distribute the URL identifying the publication in the public portal.

\section{Take down policy}

If you believe that this document breaches copyright please contact rucforsk@kb.dk providing details, and we will remove access to the work immediately and investigate your claim. 


\section{TEKST NR $83 \quad 1984$}

ON THE QUANTIFICATION OF SECURITY

Peace research series no. 1

af Bent Sørensen

\section{TEKSTER fra}


IMFUFA, Roskilde Universitetscenter, Postbox 260, 4000 Roskilde

ON THE QUANTIFICATION OF SECURITY

PEACE RESEARCH SERIES NO. 1

af Bent $S \not$ rensèn

IMFUFA tekst $n r .83 / 84$, RUC. $\quad 28$ sider. ISSN 0106-6242

Abstract

Der opstilles en simpel model til kvantisering af et samfunds sikkerhed mod overgreb såsom atomkrig, besættelse af firemmed magt, osv.

Som parametre anvendes de eventuelle fjenders evne til at gennemføre deres forehavende, deres intentioner om at gøre det, samt det angrebne samfunds evne til af afværge overfaldet.

Denne opdeling har bl.a. til hensigt at sikre en dybere diskussion af hver af disse størrelser, som modvægt mod vage udsagn om stigende eller faldende sikkerhed. Numeriske exempler på modellens anvendelse sigter således mere på at åbne en debat om de vurderinger der ligger bag parametervalg, end mod at give et endegyldigt tal for et områdes sikkerhed.

Der gennemregnes 6 exempler: Destruktiv krig imod USA, USSR, Vesteurópa og Østeuropa, samt territorial besættelse af hhv. Vest-og Østeuropa. 


\section{DH THE GUFITIFICFTIDH}

OF SECURIT T'

BENT SORENGEN

Irstitute of Mathematics, Physics and their

Fipplications in Research, Education and Society

Roskilde Uriversity Center

F O EOK 260, IKK-4600 Roskilde, Derimark 


\section{DH THE QUAHTIFICATIOH \\ DF BECIJFE T T"}

=ニ=

FBSTRACT :

$F$ simple model for quantifying the security of a society is proposed. The level of securlty is described in terms of three time-deperident variables: The CAPABILITY of potential aggressors, their INTENTIONB, and the likelihood that the soclety in question would be able to successfully defend itself and thereby fUERT an assault. The model is used to a.seess chariges in secunity since 1945 for the United statesj the Souiet Union, Western and Eastern Europe: The security a.3 regards destructive war is found to be again decreasing for all four regions, after a temporary improvement during the 1970ies. The security as regards foreign invasion and occupation of Western Europe is declining after 1380. following a long period of steady improvement. Wse of the model for assessing alternative defense policy options and future strategy is diseusated. 
It is a common belief, that a society possessing a clear military superiority over its potential aggressors enjoysa high level of security. The estimate of security levels is more irivolued for a situation of two or more societies erigaged in an arms race, such that the assignment of superiority.is uricertain at any given moment in time, and subject to possible reversal during relatiwely short time iriterials. Ore society may be superior in one area, but not in other ones, and due to the instability of the balance, it is not Even sume that there is any simple relationship betwern superiority and security.

In d. complex situation such as the ore described above, overall military strongth is a poor indleator of security. Ore must look into the specific capacities for offense and defense in all the sociaties that may play a role in a confliet situation. Furthermore, the intentions of potential aggressors have to be assessed, long with the stability or variability of their intentions.

From a professional mllitary point of view, high security is percejued in edst one has at one's disposal an across-the-board military capability, offensive as well as defonsive, and suffieient to intimidate any possible combination of enemy aggressions (Stenkiewicz, 1381). However, in a situation where the aggressor has similar capatilities, this does rot necessarily maximize the security of the society, 1.e. the security of all its members and of its basic structure and organization ${ }^{1}$.

The security of a society thus depends on the military capabilities and thieir specific $m i x$ for both the socity itself and its potential aggressors. It also depends on strategies for using the military capabilities, and more 
generally on political intentions. The present study aims at definirig a quantitative measure of security in terms of variables ("parameters") that quantify enemy capabilities and intentiors as well as one's own defense ("aversion") capatility. The reason for seeking a quantitative - albeit simple - expression of secunity is that the process of formulating the model, and of choosing its data, forces the analyst to structure his views. and present them in a way which 1 more open to outside assessment than isolated statemerits on subjective perceptions of security trerids U.SU.ally are.

\section{THE MDDEL}

In order to arrive at a quantitative model of security, the complex issues involved will have to be disentangled and formulated in well-defined terms. First, security will be defined for a spectific society or an interrelated group of societies, and furthermore, sgcurity is to be understood as being with respect to a specifie type of assault or aggression, such as nuclear war, corventional war or territorial cecupation. Dree the security with respect to such identifiable events has been evaluated, combinations of offerice types can be considered, and to the extent that the list of offerices can te made reasonably complete, an overall security may be defined in terms of a weighted sum of individual risks. This last stmp will not be attempted here, and it involves fundamental questions of methodology, because the individual thmeats to the security of a society may be of different characters rranging from death and destruction to police state methods and mind control 
exrerted by an occupying forces, which may well be eorisidered incomimerisurable.

Consider first the risk of an assault of a given type. "Risk" is defined as the occurrence per unit of time, that is the frequency, of the event in question. The risk will certainly depend on the eapacity and intentions of potential aggressors. Malevolent intent does not present any risk if not accompanied by a capabllity to carry through the offerise, and possession of the eapability does neither if there is no bad lritentions on the part of the "potential aggressors". In order to separate the soclety's defense capabilities from the offense capabilities of the enemies, the latter will be defined in terms of the force level of the potential s.ggressors, independent of the status of defense eapacities. The quantitative expression of the aggressor capability, to be denoted $F$, is

$A=$ aggressive capability of potential enemies as a fraction of that which would fully ensure accomplishment of the type of aggressive objective under consideration, and assuming total failure of defense.

Then a secorid risk parameter, $C$, is the chance of averting the assalutt by some kind of defensive action,

$c=$ effectiuity of defense, expressed as the probability of successfully averting an attempted aggression of the type considered.

Third, the thitentions of the potential agressors have to be quantified. Do we think that an assault is likely to take place within the rext year, within the next twenty year, or just how often? The parameter describing the enemy interitions iz thius a frequency, $B$, which may be defined as

$B=$ agressive intentions of potential enemies, given as the estimated probability per unit of time, that an 
assault of the tijpe consldered will be attempted.

The risk of an assault with the aggressor reaching his objective; F, maly, now be stated as the probability of an assault (B), times the capability for carrying it through (A), and not being dverted $(1-C)$,

$F=A B(1-C)$

This is obulously the simplest expression describing the considerations made above. $A$ and $C$ are pure numbers, while $B$ and f have dimension of Inverse time. More complex models could be constructed, for example to indicate that one considers the capabilities of the nnemy as more important for the risk picture than his intentions. Yet the simple model will remain a basle atandard of risk estimation ${ }^{2}$, against which ore would compare more specialized models.

Each of the parameters $A, B$ and $C$, as' well as the risk, $F$, are for glven type of assault, say the i'th type. Flacing i as a subsenspt on each quantity, the risk expmession becomes

$$
F_{1}=A_{1} B_{i}\left(1-C_{1}\right)
$$

The iriwerse of the risk is the momentary value of the average time lapse, $t_{1}$, between assaults of the i'th type. It is this quantity which in the present model will be used as a measilne of security with respect to the l'th type of offense, $S_{i}$

$$
\begin{aligned}
& s_{i}=t_{i}^{1}=\left(A_{i} B_{1}\left(1-C_{i}\right)^{-1}\right. \\
& \text { One may define an decumulated risk, } B_{i} \text {, by } \\
& R_{i}(t)=\int_{t}^{5} A_{i} B_{i}\left(1-C_{i}\right) d t,
\end{aligned}
$$

which has the form of a probablilty for an assault reaching its objective within the time interval from to to t. The walue of $t$, say $T_{1}$, for which $R_{1}\left(T_{1}\right)=1$, would be the mean 
time interival between actual ineidenees of the d'th type of aggression. Its inverse would be measure of security over a. time spar begining at the time tod and distinct from the momeritary security measure $s_{1}$, which pertains to only one point in time. The present study will reject the security measure based on $T_{1}$, because the time-integrated probability measure is considered to adequately represent the mechanisms leading to conflicts in the real world. For example, past periods of enemy intentions and capabilities, which contributed enough to $R_{1}$ to make it close to unity, but did not actually result in attempted agression, may cause $R_{j}$ to exceed unity during some later period, for which the momentary measure of risk rappens to be extremely small. The impinession of lols security induced by the accumulative approach is would thus be false. On the other hand, the momentary estimate of sceurity, $s_{1}$, is a representation of the actual risk situation, and future ehanges in the risk picture has to be modelled through the time-dependence of the parametere $A_{i}, B_{1}$ and $C_{1}$.

The establishment of time series for the three model parameters (for each type of aggression) must for past times be achieved by historical andiysia, and - in case of policy or extrapolation studies - by setting up a model of future parameter tehavior, as function of policy decisions or by extrapolation of curnunt trends. In both the past and the future cases, this kind of data acquisition involves parameter estimation usodiated with several sources of uncertalinty.

The nature of uricertidity is different for the parameter $B_{i}$ thar for $A_{i}$ or $C_{i}$. Both $A_{1}$ and $C_{1}$ depend basically on strength measures, which again derive in part from hardware counts arid in part from estimates of the effectiveness of 
given societies in using the mildtary hardware at their disposal, on to engage in non-military types of defonse. There are cledrly uncertalnites involved in translating considerations of this nature into a single number, such as the fraction of set objectives that in aggressor could hope to achieve, on the percentage chance that aciety has for averting an assalt by defensive actions. 8till, fixing past and futur values of $A_{1}$ and $C_{1}$ is basically a technical problem, and on that can be based on the evaluations of competent ilititary professionds.

The parameter $B_{q}$ desenduing enemy intentions is quite a different matter. There is no "technically correct" answer as to its proper value. It depends on policy assessment and judgement, and cannot be rigorously sottled neither for past or future situations. Different andigsts may arrive at very different estimates, dapinding on personal value systema, and data sources suth as political liadars are rarely willing to, or capable of, revealing time-sequences of aggressive intentions in the past.

Yet the value of a steurity model such as the one presented here is that it separates the "technical" Issues from the subjective judgements regarding enemy intentions. In contrast to wefping stitements of enemy intentions, like "The Sovi Union solaks world domination.", one is forced to. ask precise questions of the forim metitioned: Will the soviet Union attack us during the next yeant will it during the next fifty years? This proseure for quantification can be a very sobering exercise, and the lsolation of the most subjective parameter makes it casier to conduct a constructive discission of its value and trends, between observers with olfferent sets of prejudices.

One further kind of uncertainty involved in the parameter 
$B_{i}$, as regamds projections into the future, ds the fact that intentions can chang much more rapidly than the physical, hardware-depprident capabilities deseribed by $A_{i}$ and $C_{i}$. In onder to study the effect of this overriding source of uncertainty for times bejond the present one, the numerical examples given in the following sections will look at an uncertainty in $B_{1}$, whilen sets in at the present time and increases more and morie, as one extends the model = further into the future.

\section{DESTRUCTI WE WFR}

The type of issult considered in this section is "destructive war", which shall be taken to mean anaggression resulting in casualties of the order of fifty percent of the population in the attacked society. No previous wars have had such death tolls, but present weaponry and in particular ruclear arms have made these destructive wars possible as well as "thinkable.", in the sense that both superpowers plan for destructive wank, and seek in the name of deterrence to make it aredible that they could carry them through.

The term "destructive wan" is presently more or less synorymous with "all-out nuclear war", but it could also be effected with advanced, conventional weapons, or by use of chemical or blological wexpons. The security model outlined in the previous section will bo applied to the period from 1945 to the present, and will be further used for discussions of security. to year 2000. Just after World War II, the arsenal of ruclear weapons did not allow for inflicting "destructive wap" on any extended territory, and the possibility of linflicting so pet. casualties with 
conventional weapons were then small, s.s peflected in the choice of the "enemy capability" parimeter $A$ (In this section the type index "i!" is omitted, because only one type of assault is dealt with).

Before looking closer at the parameter choices, the societies for which security is to be estimated have to be defined. The model will be used for four societies/groups of societies: The Urited States (US), the Soviet Union (SU), Western Europe (WE) and Eastern Europe (EE) not including the soviet Union.

Consider first the enemy capability, $A$, for inflicting "destruction" as defined above. In the cases of the US and the sll, the enemi is taken as the other superpower. For WE, the eriemy is taken as the 8U, at least up to the present time. In the future, one might consider nuclear, terrorists or the possibility, that the US might conduct a limited war against the SU "through proxy" in Europe. Neither of these possibilities are considered in the standard scenario for the period 1985-2000. To small extent, the enemy of the SU could be extended to WE, Just after WW II sprimarily the United kirigdom), and perhaps s.gain towards year 2000 (France or more likely a new military alliance between France, West Germany, Itsly and perhaps the UKS. FInally, for EE, the "enemly" Maly comprise all the three other regions, US, SU and WE. However, while the SU is the main enemy as regards foreign occupation; it is not with respect to nuclear war "the reverse "nuelear war by proxy" scenarlo is less likely for SIJ-EE, becaluze of the physical proximity of the two regionsy. The main enemy for EE as regards destructive war remains the US, with WE going along but not likely conistituting an iridependert threat, except in the future event of a new military alliance in WE. 
Fischer (1983) mentions three ways of determining enemy capabilitifs: 1) counting inditary expendltures, 2y counting weapons and 3) playing war games cbattle simulations. surely, military expenditures may misrepresent sctual capabilities, because good and bad investments are both counted with full weight, flso wespon counts may be decepti'us, if the battlefield officiency of the weapons is poorly known: or if personnel or organizing capacities for using the weapons are lacking in number or qualdty. $f$ statistical analysis of the outcomes of battle simulations would in theorly give the best answer for the combined parameters of attack capablitity and aversion potential (A and $C)$. Howewer, existing game models are highly idealized and mostly orierited towards testing strategic doctrines or toluards tactical tmaining of officers. Fis measures of capability they are hardly superior to hardware counts. The selection of the parameter f for the present study is therefore primarlily based of wapon counts, but an ffort is made to avoid the pitfalls mentioned by more detailed assessment of weapon types, qualities and modes of use.

The data parts of Figures 1-4 show the values of $A$ chosen for the four regions, as function of time. By 1949, the US possessed a few hundred nuelear bombs and the su but a dozen. Deep penetration was possible by air lauch only. Tactical nuElejir bombs became deployed in Europe, notably by the US as countermedsure againat SU superiority in numbers of soldiers and conventional arms. Th1s is the reason for letting A increase between the exablishment of NATD in 1949 and the mid-fifties, for both WE and EE. The nuclear threat continues to increase for all regions after the iritroduction of rydroger bombs in 1953, and the accelerating deployment of strotegic launchers, ICBM's, on submarines or land. 
Ffiter 1960, new qualitative changes took place. US Defense Secretary Robert MeNamara introduced the concept of "assured destruetion", which was interpreted as the capability to kill one fourth of the SU population and to destroy half of its industry after a first strike by the SU. In termis of . weapons this is interpreted as a surviving serond Etrike capability of 1200 megators of TNT equivalent on about as many Independently targeted misslle heads (Kaplan, 1982). MeNamara further introduced the notion of "flexible response", demanding a much larger arsenal of specialized nuclear weapons, differing in size and precision, to be able to selectively attack military targets, industrial targets and population centers. The time-urgency of strikes against certain military targets made it imperative to improve the command and control capacity, which among other things meant the establishment of a satelilite surveiliance system. The bullaing up of these capacities took place over the following years, as reflected to some extent in the development of the parameter $A$ for the SI arid EE. Howewer, A flattens out becusse the purpose of the US policy charige is not primarily to inerease the total destructive power, but rather to add new weapon types ofter of relatively low ylelds - in order to suoid having to use the mass-destruction wexpons early in a coriflict (counterforce as opposed to countervalue strategy). This development will be reflected in the intent parameter $B$, but it affects $A$ only insofar as the total capability for destruction is iriereasing.

During the 19601 es, the SU effort is one of catching up with the USS, and to actualiy produce the nuclear arsenals claimed to be in existence in the late 19501es, By 1968, the SU had catched up on the number of ICBM launchers, arid both 
powers began to harden silos and improive accuracy. It is generally agreed, that by 1970 there wa an overall parity between the US and the SU, with mapect to the number of strategic warheads ${ }^{3}$. For particular weapon systems there were differences. The US SLBM's had been operative since 1966, and the 34 did not catch up unt11 1971. The reason that the parameter $F$ di taken a larger for enemy capacity againat the US than dgainst the SU in situations of weapons parity, is purely geographical: It takes a larger. megatonnage to destroy half the SU population than to destroy half the US population.

From the begirining of the 1970ies, the capacities were increased by III'y' ing of ICBM's, and Improwed sceuracy of SLBM' $s$ buriught these out of the confinement to countervalue uses. Wome of these qualitative developmerits have significant influence on the parameter $A$ as it is defined here.

For EE and WE, the enemy capability, F, reached a high value (taken as 0.8) already in the beginning and end of the 19601es, respectively. Rgain the difference in the values of $A$ as compared with those of the US and the 84 are of geographical origin. From 1979 a worsening of the situation in the tivp Europes took place, due to the rapid deployment of new ss-2g missiles and later of eruise missiles, due to derreasing warning times and vulnerability of command and control centers (e.g. because of Pershing-z missiles), and due to an owerall increase in the number of targets that may te wiped out in a first strike STrident 2 and Soviet counterparts). Full deployment of these weapon systerns would be completed around 1990. For WE and EE, the value of $A$ has presently reached a level nearly equal to one, and for the US and the $S U$, it $1 \mathrm{~s}$ assumed to memain at 0.7 , based on the 
consideration that none of the weapon systems existing or proposed can fully onsure destruction of societies which are a.s dispersed as the US or the SU.

The intentions of potential aggressors, i.e. the parameter E, can be etstimated on the basis of an analysis of political statemerits, inteligence information, published stritegy and battlefield conduct material, or by theoretical modelling such as determence theory caimed at modeliting the influence on enemy interitions of various force postures, in order to find say the least expensive force posture which is sure to deter the enemy from agressions. Deterministic models of enemy thinking are likely to fail, due to omission of factors such as histondeal prejudice, leadership psychology and the influence of a large number of smaller. Everits in international policy, which are considered insignificant or too numerous to include in operationial models of erieriy behavion. The choice of the, parameter $B$ Ehown in Figs: $1-4$ is primarily based on public sources stating or exploring national stragegies and political attitudes towards aggressive activities".

Diespite general political statements on the "Inevitability of war" reaulting from contrasting ideologies", the SU has hardly had any real intentions of attarking the US itself during the period 1945 to now. "Ietente" his.s been seen by soviet leaders as the only realistic kind of relation with the us (Mamontov, 1979 ). Towards (parts of') WE, the SU may have had some aggressive intentiors until 1949, when NATO was formed and the "nuclear umbrella" of the US became extended to WE. When the Mccarthy cold war syridrome spredd ower the US, a. US attack on the SU and $E E$ became (or remained) quite thinkable despite increasing SU rilelear strength. The flgure chosen for US 
aggresslue interitions is 0.2 per year (one in 5 years) in 1348, when there was a U8 monopoly on nueleam ams, pising to $0.25 \mathrm{y}^{-1}$ in 1950 (Komean wand, declinding bit at the death of stalin, but reaning a new height of $0.3 y^{-1}$ during the cuban missile crisis in 1961.

The aggressive intentions of the SU are lower and during the late 1340 ies dimected mainly towards WE. They inerease until $19 \epsilon 1$, due to the impact of the cold war and due to the confidence associated with increased SU nuclear capability.

The positive contact established between John Kernedy and Nikita Khrushche's lead to decressing uS interitions of destructive war against the SU, and the doctrinal changes brought about by Mchamara as a consequence of tha shortcomings exposed duming the missile crisis must have had a. similar effect, although it was until after 1963 (partial test ban agreement), that the SU defacto accepted the doctrine of "mutually dssured destruction" (MFI). By 1963, the aggressive intentions of both sides have been estimated as down to $0.1 y^{-1}$, and during the following period of detente (to about 1979), the aggressive intentions continued to diminish.

From the late 1579les, ideas of a successful first strike seem to play a role among US military strateglsts. The SU has formally disavowed that they would strike first, but an "automated resporise" in case of US attack is often emphasized (Garthoff', 1981). Since both WE and EE are nosting large numbers of superpower controlled nuclear weapons; the adoption of such strategies by the US and the SU dimounts to obivious increases in the risk of Europe being destroyed, so in this wiy both the UB and the SU presently coritribute to the "enemy Intention" parameter B for WE (and similarly for EE). Furthermore, the US has recently adopted 
atrategy calling for preparedress to conduct protracted ruldear wars SRichelson, 1983). The weapon systems and Weapon uses envisaged for a protracted nuclear war between the superpowers may ddd to the probability that EE and WE will be destroyed, during such a war. Only if the war could remain limited (in dumage), could the Europeran security gain by such strategies. and this possibility seems at present excluded because of lack of sJ acceptance. On the contrary. siny IJ efforts to limit a nuclear war to Europe and to selected targets may well enhance the soviet advantage of a full-seale, destructive attack at an early time during a confliet. The SU agressive intentions towards WE may well increase, if the su believes that the US will not react by full-scale nuclear war; but by some limited response, at lesst initially. For this reason the current development is seen as probably leading towards an inerease in the parameter $B$ describing 35 aggressive intentions against WE, even if this is not consistent with the general SUJ perception of the US as the main adversary and WE as a relatively friendly region.

The extrapolation of the model into the future further assumes a rapid increase in U8 agressive intentions towards the EU, reaching $0.3 y^{-1}$ by 1995 cand same for EEj. The motivation lusuld be a US belief to have regained superiority, due to its fforts to safeguand its control and command struftume, an emorging space war capability arid the possible deployment of anti-balilstic and worldwide operative anti-supmanine defense systems. The reaction of (rield) Sowlet lesders may be to consider war with the US as unavoidate and then to go for the advantage of a first strike. The various arguments presented above are translated into intention parameters of 0.1 and $0.3 y^{-1}$ for the US and 


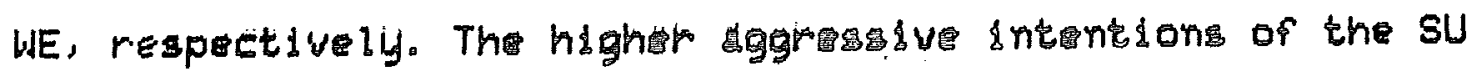
towards WE, as a roflestion of the possible scceptanes by the su of limited war coneepis, eloknly constitutes just one of many concedughl modele of future su behavior.

A factor contributing to destuet the UE may towands. Jyar 2900 also be torromist groups,

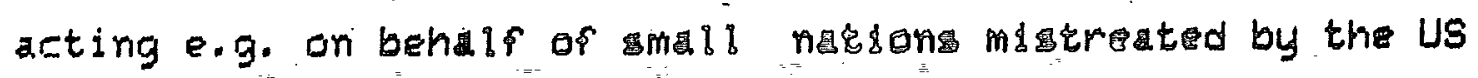
cCentral fmerican counindes being obvious enndidaces). If

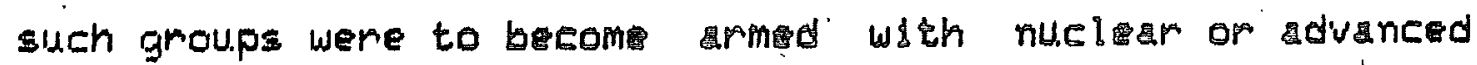
biological weapons, they could consedicure noticable destructive threat.

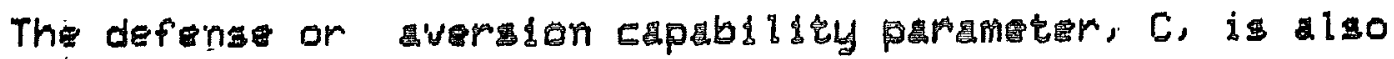

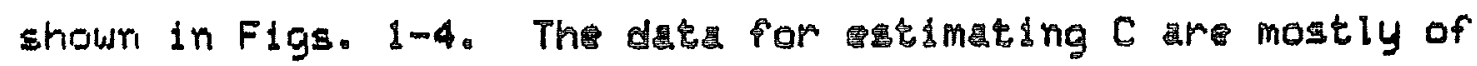

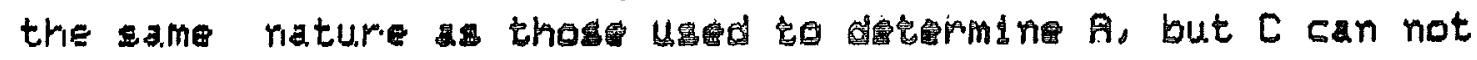
fully be determined by mildiary hroware it contains components influenced by chodes of strategy. as well as components related to defense will and attitudes in the society.

For the US, the drop in $\mathrm{C}$ botween 1955 and 1980 is aEsociated with the increasing nuelear capability of the SU during that period. The sntroduction of the flexible response doctrine during the 19601 es and 19701 es could have increased $C$, because it may be seen as a counter-measure agairist fully destruetive ruclear wars, but this effect is uncertaln due to lack of soviet enthusissm for the doctrine (it takes two to play a limited nuclear war). Fis the offensive nuelear arsenals inerased in quantity and quality during the period, the actual value of $C$ for both the US and the su is taken as declining. Sharp drops in the defensive potential occur when thi opponent introduces (invulnerables SLBM's, that is for the SU value of $C$ in 1966 , and for the US in 1571. 
A further decrease in $C$ takes place 1980-1984, due to shorter warning times and inereased vulnerdbility of command and control facilities (Bracken, 1983).

For. WE, the parameter $C$ is influenced by the same events. The iritial value after 1945, however, is very low due to the post-war exhaustion. Some improvement is seen as a. result of the formation of WATO in 1949. For EE, the defensive eapability remains low all the time, due to soviet control of defense development.

The model of the future benavion of $C(1985-2008)$ assumes rather arbitrarily; that the UB succeds in extablishing an effectiwe anti-submarine defence around 1990, and that its. deficioncies in command and control survivatility are by then eliminated. The 3U 1 is then assumed to acquir a similar anti-submarine capability by 1995 and thereby to again nulitiy the US defence superionity. This situation is repeated, when the us in 1999 acquires a star-war type of missile defense system, followed by thi BU one year later. These scenarios are constructed for lliustritive purposes only.

Figs. 1-4 show the model results for the security $s$ of ejch of the four reglons, and the effect of assuming an uncertainty in the future vilues of $B$ (enemy intentions); but ro uncertairity in the other parameters. The form given to the uncertairity interval i(t) around $B(t)$ is

$$
I(t)=\left[\frac{B(t)}{1+k\left(t-t_{p}\right]}, B(t)\left(1+k\left(t-t p_{p}\right)\right]\right.
$$

where $k$ is taken as $0.1 y^{-1}$ in the present example coorresponding to an uncertainty interval which after 10 years stretries from B/2 to $2 B$ ). The uncertainty sets in 
after $t_{p}=1984$ (the present time).

In Fig. 1, the model rosults for the security of the US between 1945 and 2000 are presented. Before 1960 , there was no slgniflearit risk of a destruetive war against the US, but during the following decade, its securlty drops rapidly. In 1970 the risk of a dustructive assault is estimated to be ore in 40 years. The reasons for a decilining US security comprise the rising nuclear capability of the SiJ as well as the diminishing chance of conducting an effective defense against a growing arsenal of nuclear weapons. US security improves between 1970 and 1979, due to deelining aggressive intentions by the su. However, security corresponding to ore destruftive assault each 50 years may still be considered ss quite uncomfortable. From 1984 to 2000 , the scenarios studied do at best lead to a security level more or less staying at the 1984 level, at worst to decline in security to over 10 pct. "chance" of a destructive assault in a given year cmore than once in ten years). It all deperids on Sowit reactions to the recent change in US policy, and or the interplay between any further policy changes by the tivo supdrpowers.

The security of the SU, shown in Fig. 2 , is also impeccable just after WW II, but it starts to drop already during the early 1950tes, because of the US nuclear superiority. Juring the Cuban missile erisis in 1961, sU security reaches a low of one dastructive assault in 20 years, corresporiding to a 3 pct. chance of such an event during 1351. During the period of detente, 1963-1979, the risk of assault upon the $8 \mathrm{U}$ was about one in 40 years. The UB policy and increased sggressive intentions since 1980 result in a new dnop in 8U security. By 1984, the risk of destructive war is 10-15 pet. per year, and in the future, 
security may elther improve or dwind to towards zero, dependirg on further changes in us policy.

Fig. 3 skows the model mesulte for WE. Just after WW II, security was high lthough not is hlgh as that of the US and the siJ. Between 1953 and 1961, the security of WE behaves similarly to that of the SU, and between 1961 and 1979 it steadily improwes. The calculated values in 1961 and 1979 are proctically identical to those of the SU. From 1380 to 1334, WE security orops to a chance of destructive assault amounting to about $\mathbf{5}$ pet. per year, mainly as a result of the reaction of the su to the inereased aggressivity of the 15S. It is interesting to note, that the model assigns a grieater 1984 security to WE than to the sU, despite more aggressive capability directed ugainst WE and despite its lesen tharice of sucesssully defending itself against a nuclear assajult. The reason is that the aggressive intentions associated with the anti-communist orientation of the US since 1980 ine much stronger than the aggressive interitions of the SU towards WE. The future security of WE may idwindle towards zeros if the SU should consider a eonifroritation with the US as unavoidable, and if WE does not successfully disengrge itself from the superpower rivalry.

The ealculated security of EE is shown in Fig. 4. Its development in time is similar to that of WE, but the absolute level is roughly half of that for WE. The reason is malrily to be found in the simflarity of enemy intentions to those directed agulnst the 8U, becuse the combined estimate of enemy capabilities and defense options is no more favorable than that of WE. 
The type of aggression derit with in this section 1 s termitorial occupation and control of gociety by a foreign nation, achiwed edther by military dnwation or by some other. form of coercion. Dceupation my follow destructive war, but the more interesting securdty problem is that of foreign occupation without massive destruction. The model of security presented in section 2 ex be applised in the same way a.s for destruetive war.

Ir case of the US and the su, enemy capabilities for occupation without previous destruetion are small, and deferise prospects are good. Therefore the security will be high ro matter which intentions a potential aggressor may have. When translated into the model measure of security. this corresponds to way over 200 years betwen incidences.

Much more relevarit cases are those of WE and EE, for which territorial occupation by the SU constitutes a real threat. Figs. 5 and $\epsilon$ show the parameter sets used in the andysis for these two regions, wong with the model MEsUlts.

The parameter $A$ deseribing the capability of the su for invading WE or. EE is taken to be around 0.5 for WE and close to unity for EE. The aversion parameter, $C$, exhibits more wariation: Right after WW II, most of WE were unable to defend itself against soulet invasion, and $C$ was low. The formation of NATO led to an upgrading of defensive capability, and the subsequent development of operative corventional forces in WE caused an increase in $c$, which by 1970 is assumed to have reached a value of s.bout 0.5655 pct. change of averting in invasion or of shaking off an attempt s.t political comeion). A slight reduction in $c$ is introduced during the following decades, due to WE emphasis 
on ruclear weapons and to claimed economic difflculties in maintaining a. strong conventionil force posture. The assumptionis that nilelear weaporis are less useful in averting an attompted occupation not accompanied by mass destruction because the use of nuclear weapons would be 'ikely to escalate the war to a lovel of assured destructions.

In the case of EE, the defense cupability has until how been lower triat in WE, due to actual coersive interference by the su. There are elear setbacks in the walue of $c$ at the times of the su interventions in Hungary (1956) and [zechoslowakia '(1968). The current trend' of inereasing diaergagement of the EE countries from the SU 18 in the model assurred to lead to an Increasing foreign occupation ziversion capability C, reciching the WE walue by year 2000.

The question of US foree withdrawal from l. 18 not considered essential in fixing $c$ for WE, because the indigerious deferise capability is presently dominating the charice of averting in invasion with territorial goals. Some may argue that U8 reinforcement is erucial in case of Invation of lUE by the SU, but the point of view taken here is, that if the confliet is not settied s by either a de ficto occupation or by a successful aversions by the time that relnforcement could reach WE, then 1t is certain to develop irito a destruetive war.

Finally, there is the parameter. B describing su interitions. Intentions of invading We are corisidered small, with some increase around 1948 (the temptation ereated by lack of deferise) and around 1961 (general tensions. Hs regards EE, the SU has constantly botn seeking to control this "buffer zone", but during most of the period 1945-1985, the SU has found it best to avoid actual oceupation if 
political toercion could to the job $6 \mathrm{~g}$. in the case of Foland, 1981). The intention for occupation, $B$, is taken as around 30 pret. per your conce in 3-4 years, in accordance with sequences of actual events including the use of coercive pressures to achdve the same prods as with military occupations. The current tendency is for a modest decline, but with great uncertainty concerning thi future values of B.

One model of future su intentions would have a new mise in $E$ as regards occupation of both EE und WE, as a result of the increased (destructive wars intentions of the US towards the SU. The SU leaders may decide, thut a conflict is unavoidable, and mily try to exploit the advantages of starting, E.g. by full occupation of EE and WE.

The resilt of the model assumptions deseribed above is that WE security increased from a post-war level of one occupation in 50 years (1945-1969) to a high of one orcupation in 200 years (1979). Fig. 5 further shows that a. decline in security agdingt occupation of WE takes place between 1979 arid 1985 , and possibly continues during the next decades, but with clouds of uncertainty deriving from the possible developments in SU intentions.

For EE, the security has been consistently low - around ore occupation or similar coercion every 3-4 years - but with signs of a possible improvement during recent years, which may or may not continue in the future.

\section{I SLUSS I DM}

The quantitative model of security discussed in this paper is designed to llow a separate discussion of the key 
Elements in the snsilysis of secumity with respect to given threats. If its results differ from those of alternative methods of analbsts, it should therefore be possible to enter a mearingful search for the precise difference in assumptions that gives rise to the disagrement, whether the difference is associated with data selection or with model strueture.

Ore clearcut example of such a, check would be the security agsirist destructive war during the Cuban missile erisis in 1961. The present model predicts a 5 pet. chance in that year, that the su would experience, a destructive nuclear war. Dees this figure agree with estimates based on political pheriomenology? Does it agree with other models of security, that maly be proposed?

ficcepting the present model assessment, important issues maly be risised for discussion: How will the su respond to the spamatic dmop in its secumity since 1980 6Fig. 22? The same question may be aked for WE. The model indicates that WE efforts to create conditions of peaceful coexistence with the SIJ were largely successful from 1960 to 1980 beconomic collaboration and German "Dstpolitik"2. How can this path be regained? Fre the WE and US security interests so different. that a. European disangagement from the military preparations and etrategies of the superpowers is necessary? If so, how should the defiense polley of WE be neshaped?

The preserit model may be used to look into the security Implicatioris of varlous paths, in terms of the parameters choser to describe alternative options. In WE, there is an ongoing discussion of at least three alterratives: fri inidependent riuglear defonse, a strong conventional defense coorientional both in the sense of "non-nueleap" and of "traditional military" defendes, and finally a territorial 
defence with little offensive capability ${ }^{6}$. The model would be used to trace the developinent in security for each of the alterratives, along with the uncertainty eatimated to surpound each option. The alternative security results would be compared to each other and to the "standard" scenario (o.g. as expressed in this work), and if differences in cost can be estimated. It will be possible to determine the least cost of reaching a desired level of security, within the range that can be achieved. 


\section{HOTES}

1. A similar definition of security, is used by the Aiterrative Defense Commission (1983).

2. It is often denoted "dlmect risk" in risk analysis csee Sorenseri, 1982).

3. Sources iriclude Kaplan (1982), Beer (1981), Thee (1976) and SIFRI Yearbook (1978-1983).

4. Sources include Ball (1988), Meyer (1984), Sienklewicz (1381), Darthoff (1981), Douglass (1980), Bracken (1983) and Richelson (1583).

5. Rlthough the concept of limited retaliation was iritroduced ny Meflamara in the eanly 1960ies, it was not made fully operational until the mid-1970ies, under Defense Gecretary James Senlesinger (see Bracken, 1383:66).

E. 3eti e.g., review by Dankbaar, (1984). Fi discussion of territorial defenge in EE may be found in Jones (1981), and b.sis thoughts on a us defense based on non-offensive wexpons in Boston study Broup (1979).

\section{FEEFERENCES}

Flternative Deferies Commlssion (1983) Defense Without the Bomb. London: Taylor \& Francis 
Ball, D. G1980) Poldties and Foree Levels. Berkeley, CA: Univ. California. Press

Eeer, F. (15a1) Feace sgainst War. San Francisco, CF: Freemsin \& Co.

Boston Sturdy Group (1979) The Price of Defense. New York: Times Eooks

Bracken, F. (1983) The Command and Control of Huclear Forces. New Haven, CT: Yale Undu. Pross

Darikbaz.r, B. (1984) "Alternative Defense Foldcies and the Peace Movement". J. Peace Res. 21!141-153

Douglass, J. (1988) Soviet Military Strategy in Europe. New York: Fergemon Press

Fischer: [. (1983) "Conceptual Models, Judgment, sud the Treatment of Uncertainty in Nuclear Threat Fissessment". J. Soc. Issues, $39: 87-153$

Barthoff, F. (19B1) "Mutual Deterrence, Farity and Strategie Frms Limitations in soultt Policy", pp. 92-124 in D. Leebaert (ed.) Soviet Military Thinking. London: Allen \& Uriwin

Jonas, C. (1981) "Bovlet Military Doctrine and Warsaw Pact Exercises", pp. 225-258 in D. Leebuert (ed.) Soviet Military Thinking. London: Allen \& Unwin 
kaplan, $F$ : (1992) "Strategle Thinkers". Bull. Ftomic Efientists, $38: 51-56$

Mamorto's: "1979) Dlsarmament - the Command of the Times. Moscou: Frogress Publ.

Meyer, E. (1984) "Soviet Theater Nuclear Forces. Part I". Fidelphi Papere No. 187. London: Int. Inst. of Strategie Studies

Rithelspri, J. (1983), "PD-59, NEDD-13 and the Reagan Strategic Modernization Program". "J. Strategic Studies, E: $125-146$

Sienkiebicz, 5 . (1981) "Soviet Nuclear. Doctrine and the Prospects for Strategic Arms Control", pp. 73-91 in $D$. Leebsert (ad.) Sóviet Military Thinking. London: Allen \& Unuin

SIPRI (1978-198.3) Stockholm Int. Peace Res. Inst. Yearbook: World Armaments and Disarmament. London: Taylor \& Francis

Sorensen, B. (1982) "Comparative Risk fsgessment of Total Energy Systems", pp. 455-471 in Health. Impacts of Different Sources of Energy. Vienna: Int. Atomic Energy figeney

Thee, M. (1975) Firmamants and Disarmament in the Nuclear Rge. Storkholm: Almquist \& Wiksell 


\section{FIGURE LEDEHDS}

Fig. 1. Data and model results, for destructive war in the United states

Fig. 2. Data and model results for deatructive war in the Soulet Union

Fig. 3. Ijata and model results for destructive war in Hestary. Eur.ope

Fig. 4. Iata and model results for destructive war in Easterin Europe

Fig. 5. Data and model results for foreign occupation of Western Europe

Fig. E. Ilata and model results for forelgn occupation of Eastern Europe 
DESTFUCTTIE WFR FOFIWST

\section{THE WHITED STATES}

Iata (estimates):

ROGRESSIVE CAPABILITY

OF ENEMY SFCT. DF THAT

WHICH WOULD FULL'? ENSURE

THE RGGRESSIVE OBJECTIVE)

AGGRESSIVE INTENTIONS OF ENEMY CPCT. ESTIMATED PROBAEILITY THAT EHEMY HILL ATTEMPT FGGRESSIOH WITHIH DNE YEAR?

PROBABILIT'Y OF SUCCESS IN A'VERTIHG FN ATTEMFTED AGGRESBION (PCT.)

Model result:

SECURITY SAIVERAGE YERRS BETWEEN INCIDENCES OF AOQRESSION)

[FIG I

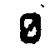

100

g

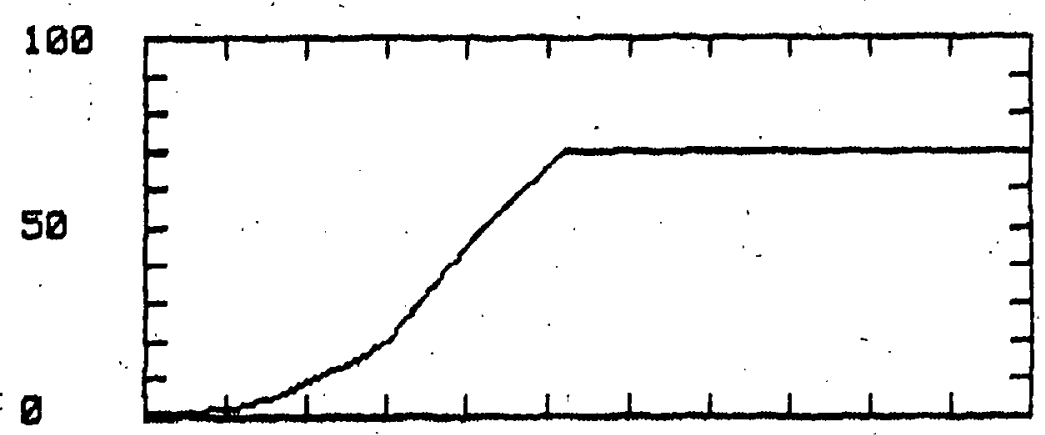

100

58

50
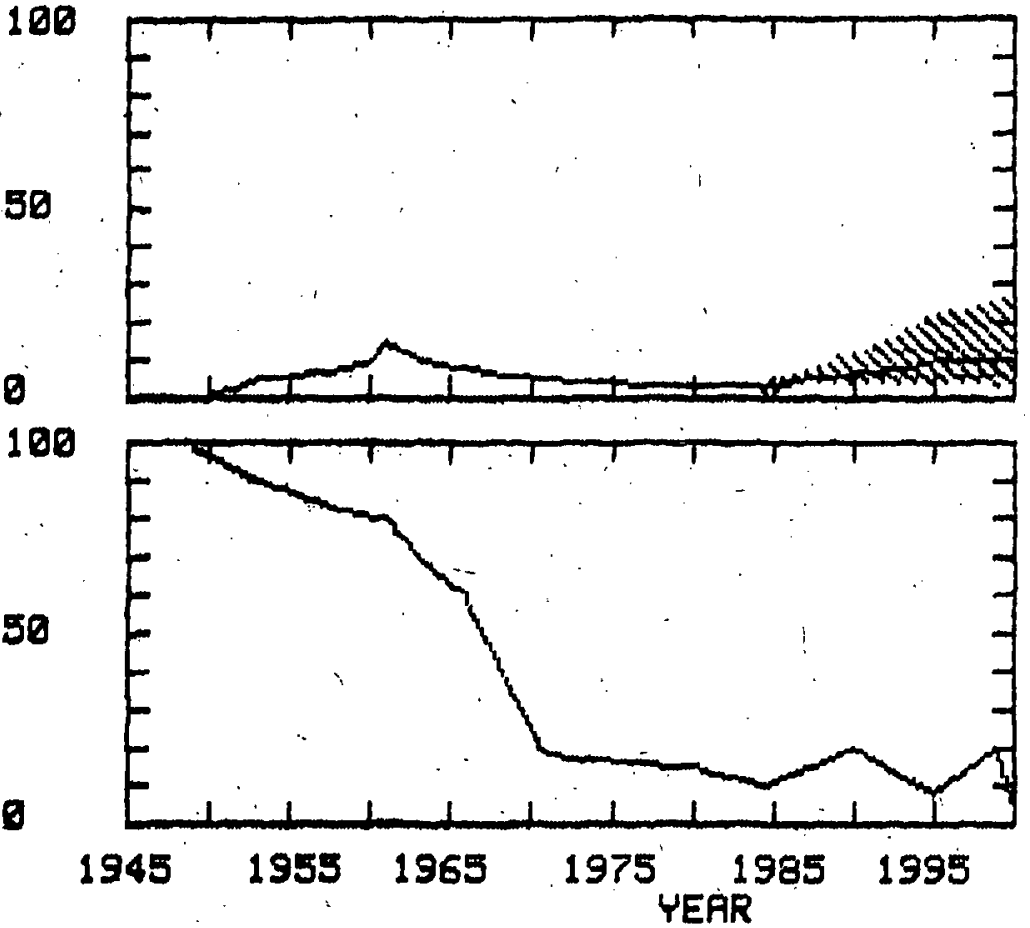

298

B

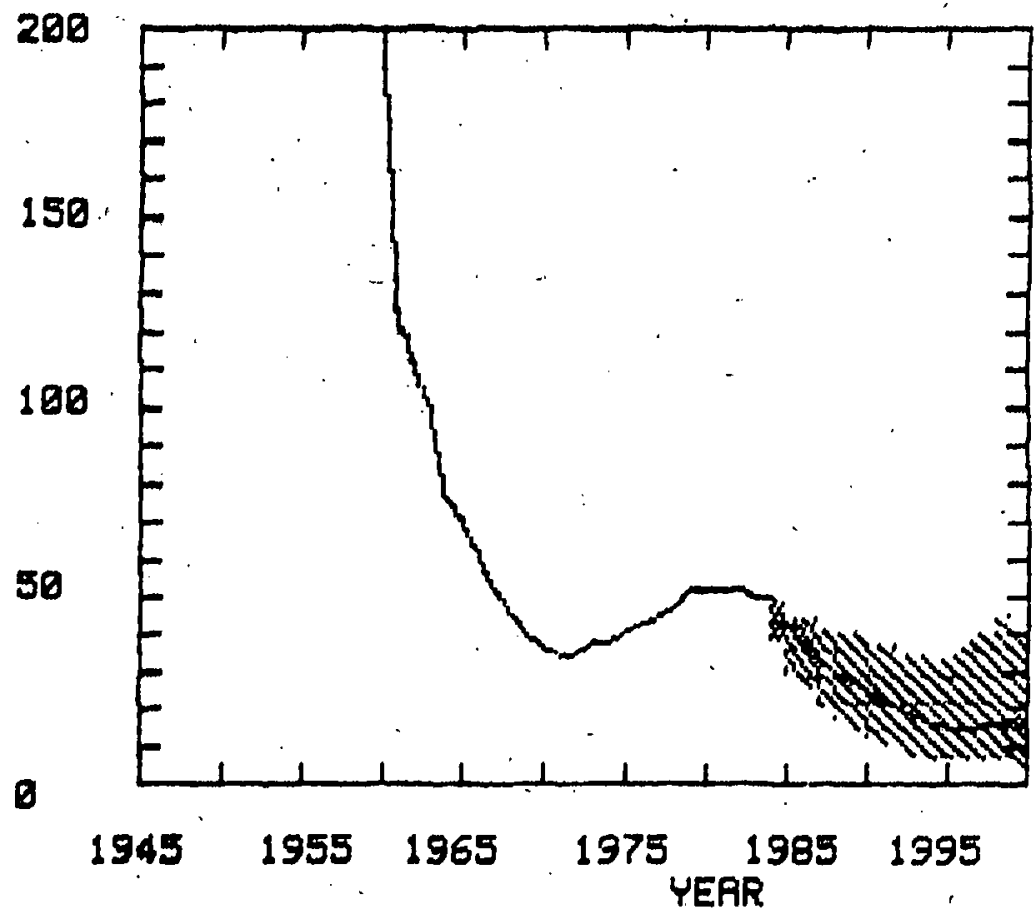

Fir 1 
DESTRUICTIE WAF PGAIHST THE SOWIET LHIL

Ilata (estimates):

AGGRESSIVE CAFRBILITY

OF ENEYY SPCT. OF THAT

WHICH WOLLIJ FULLLY ENSURE

THE RGQRESSIYE OBJECTIVES

FGGRESSIVE INTENTIONB OF ENEMY SPCT. ESTIMATED PROBRBILITY THAT ENEMY WILL ATTEMPT RGGRESSION WITHIN ONE .YEAR)

PROBABILITY OF SULCESS IN AVERTING AN RTTEMPTED AGORESSION (PCT.)

$\theta$
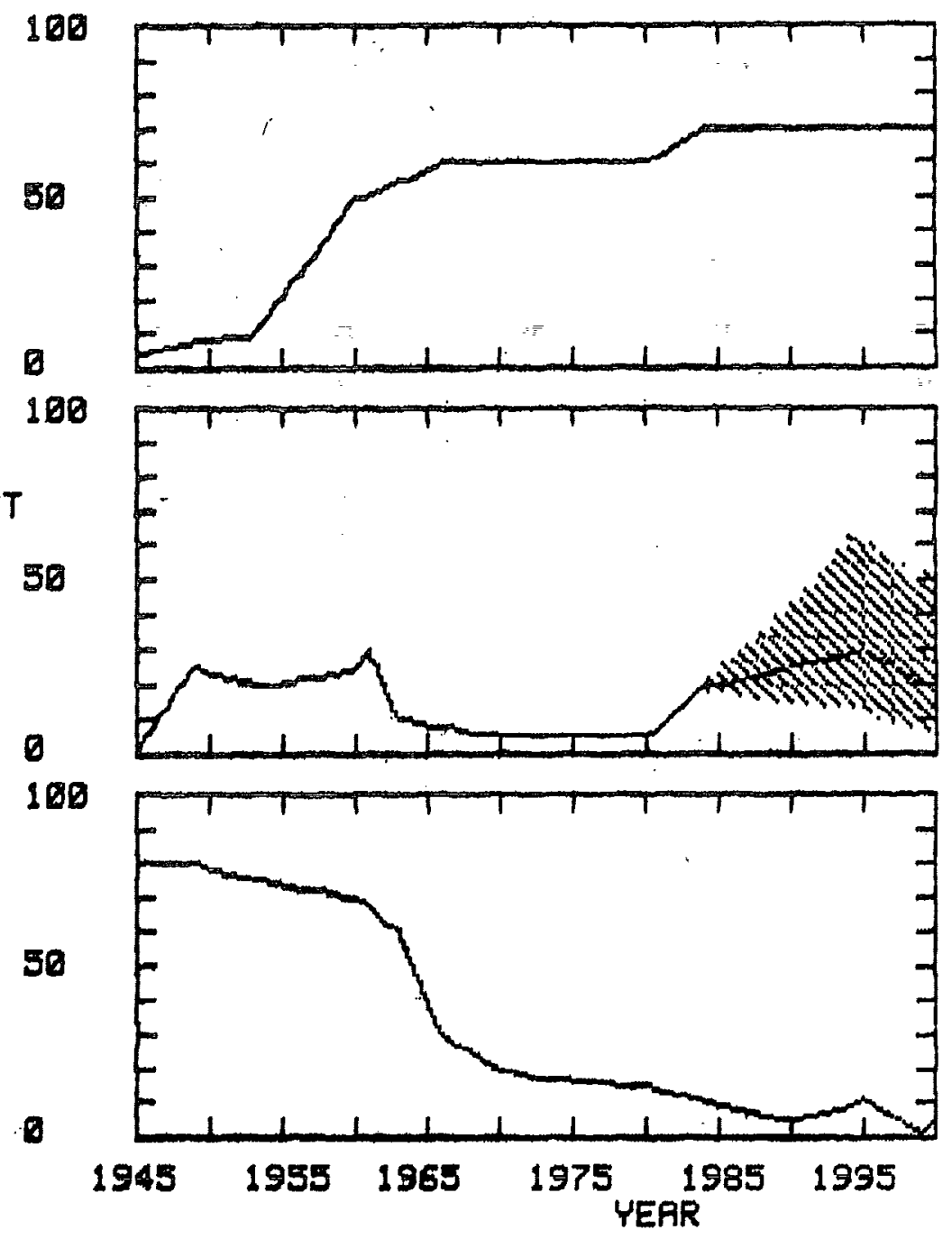

Model result:

SECURITY SAVERFGE YEARS

BETWEEN INCIDENCES DF AGORESSIOND

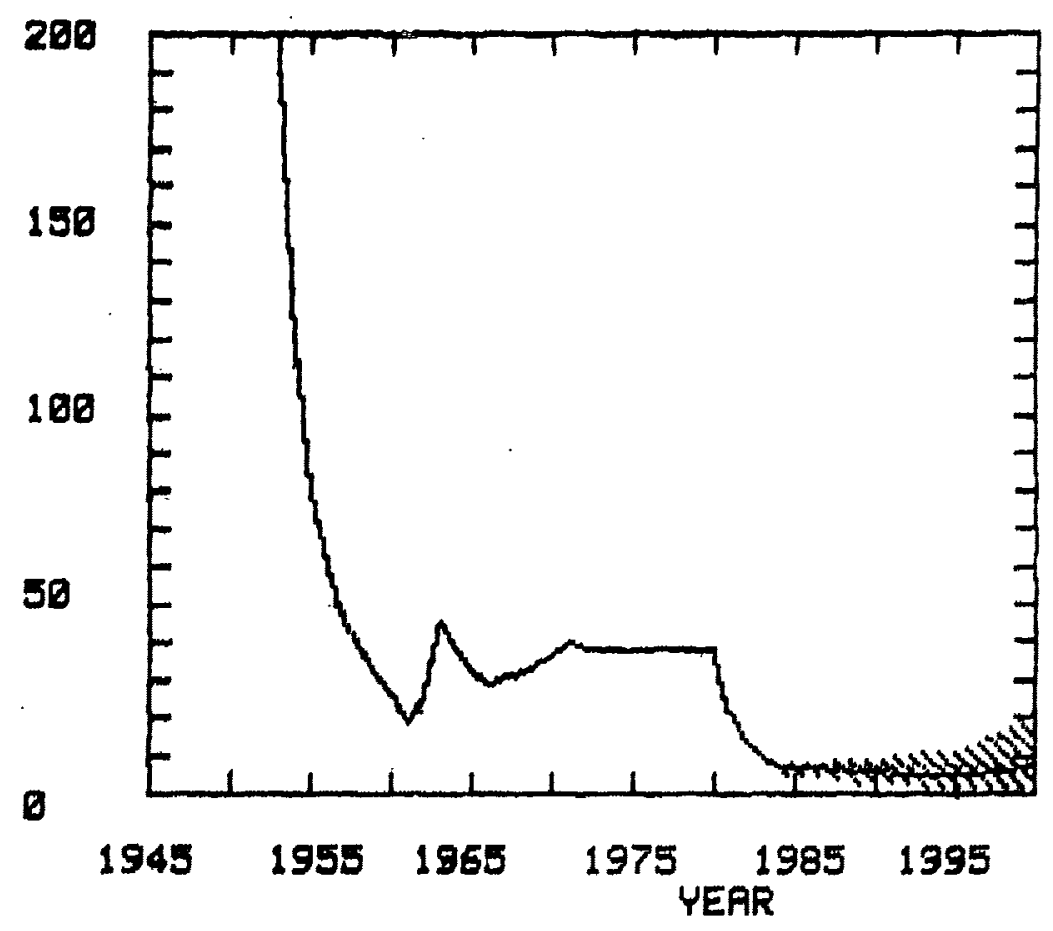

FG. 2 
DESTRUCTI WE WFR IW WESTERH EUROPE

Jata (estimates):

FIGORESSIVE CAPFBILITY

OF . ENEMYY SPCT. OF. THFT

WHICH WOULD FULLY EHSULRE.

THE RGGRESSIVE OBJECTIUE)

FGGRESSIVE INTENTIONS DF ENEMY SPCT. ESTIMATED PROBRBILITY THAT ENEMY WILL ATTEMPT AGGRESSION WITHIN ONE YERR

PROBABILITY OF SUCCESS IN AVERTING AN RTTEMFTED FOORESSIDN (PCT.)

Model result:

SECURITY SAVERAGE YEARS EETWEEN INCIDENCES OF AGGRESSION)

FIG 3
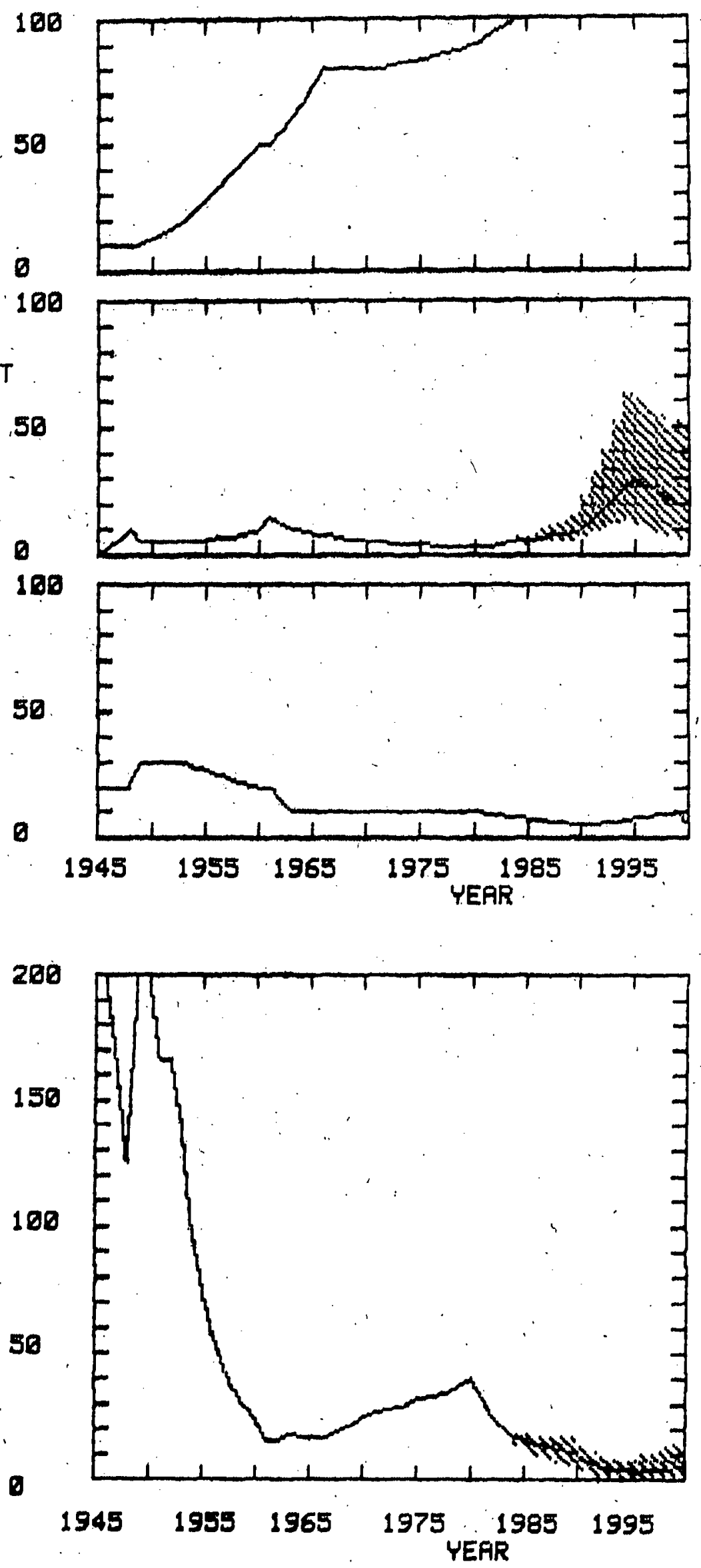


\section{DESTRUCTIME WAR IN EASTERH EURDRE}

Iatd (estimates):

ROORESSIVE CAFABILITYY

OF ENEMY SPCT. OF THAT

WHICH WOULD FIJLLY ENEURE

THE RQGRESSIVE OBJECTIYE)

FGORESSIVE INTENTIONS DF ENEMY SPCT. ESTIMATED FROBABILIT'Y THAT ENEMY WILL ATTEMPT FGORESSION WITHIN DNE YEAR ?

FROBABILITY OF SUCCESS IN FUERTIWL FNA RTTEMPTED FOORESSION (PCT.)
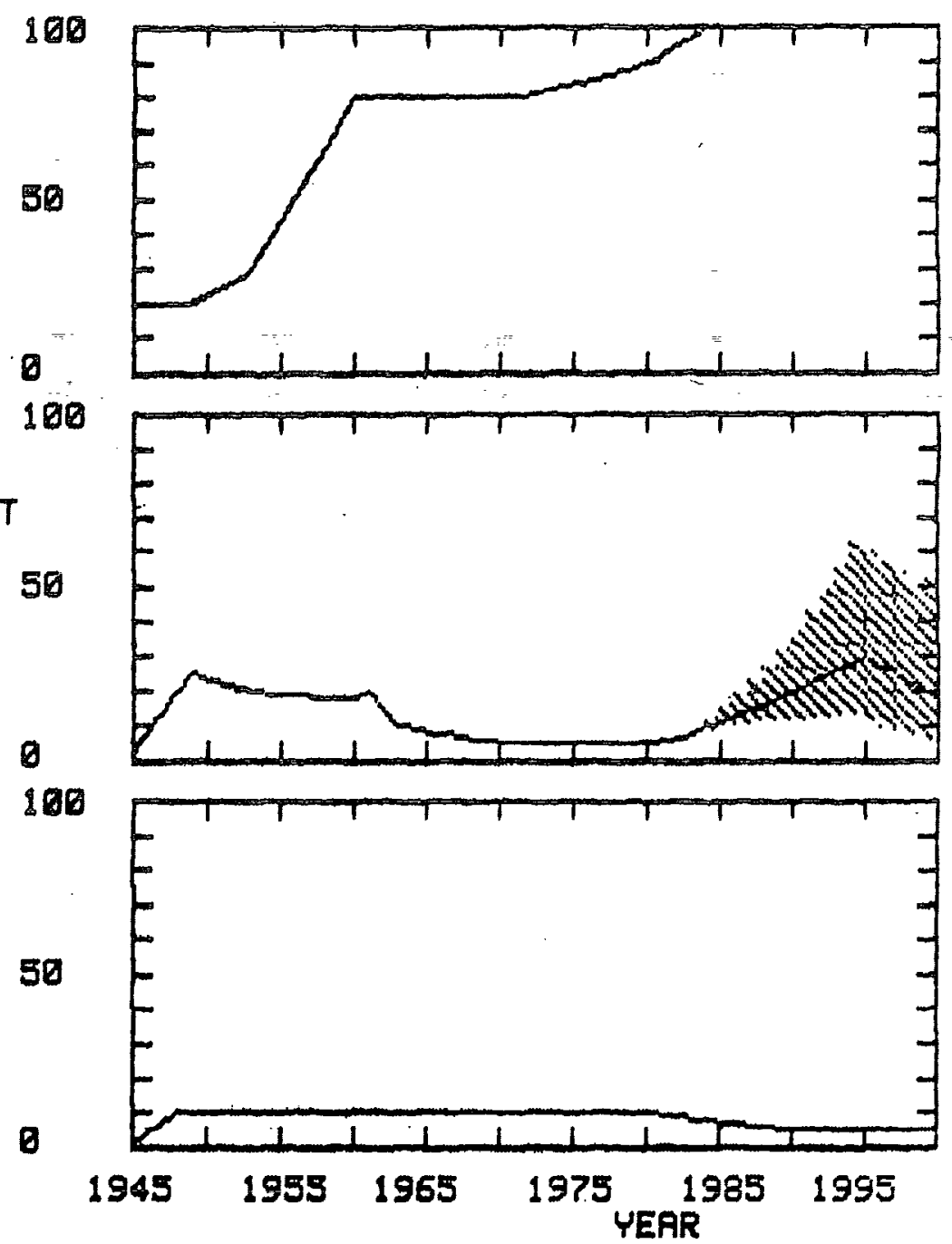

Model result:

SECURIT'Y SAVEFFGE MEARS BETUEEN INCIDENCES OF FIORESSION)

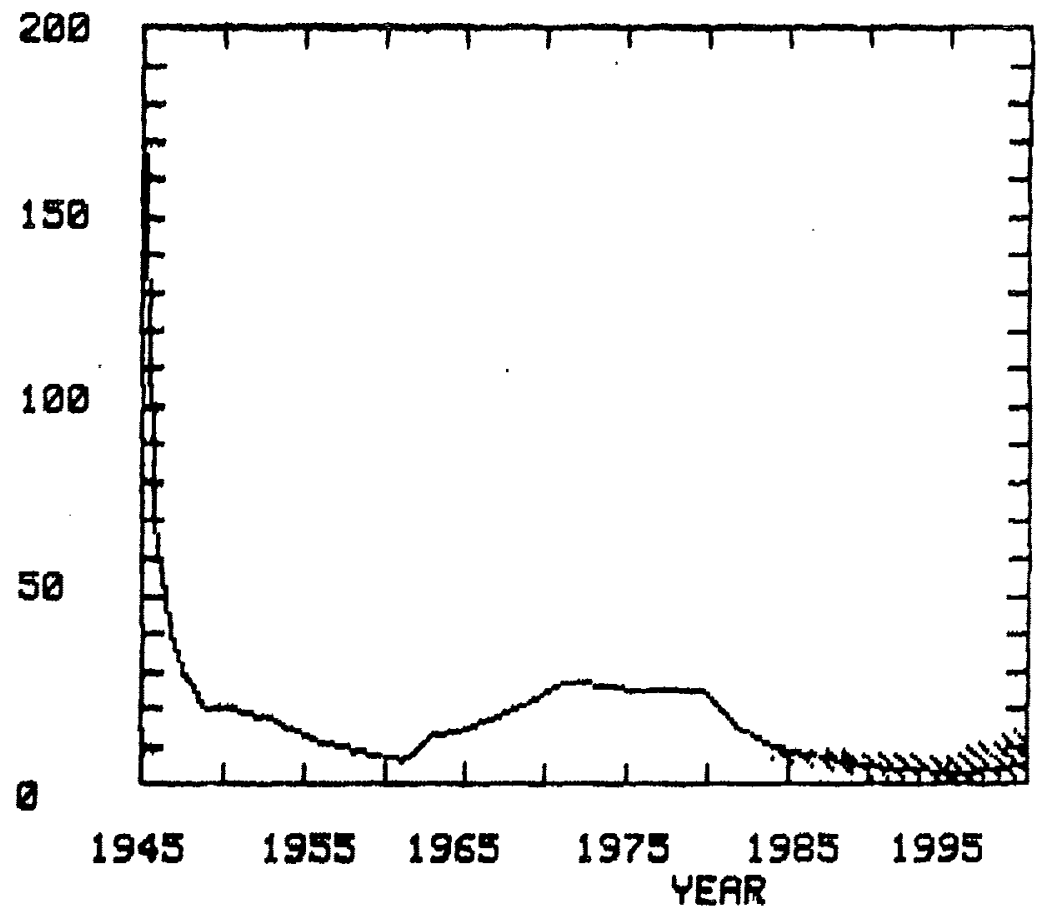

Fin." 
FOREIGH DICLUPFTIOH DF WESTERH EUROFE

Data (estimates):

RGORESSIVE CAFABILIT'Y

OF ENEMY SPCT... OF THAT

WHICH WOULD FULLY ENSIJRE

THE AGQRESSIVE OBJECTIVE)

FIGORESSIVE INTENTIOHS OF

ENEMY SPCT. ESTIMATED FROBP-

FISGRESSION WITHIH OHE YEAR)

FROBRBILITY OF SUCCESS IN FWERTING AH RTTEMPTED FIGQRESSION (PCT.)
EILITY THAT ENEMY WILL FTTEMPT

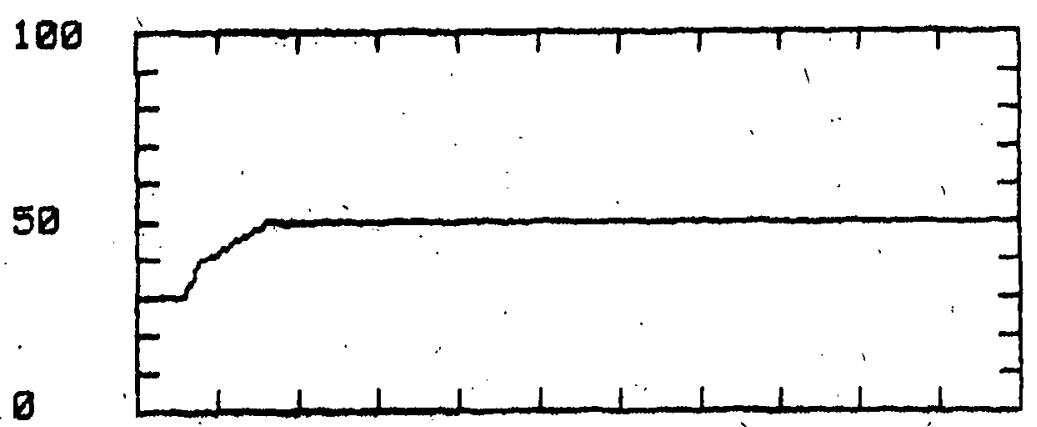

100
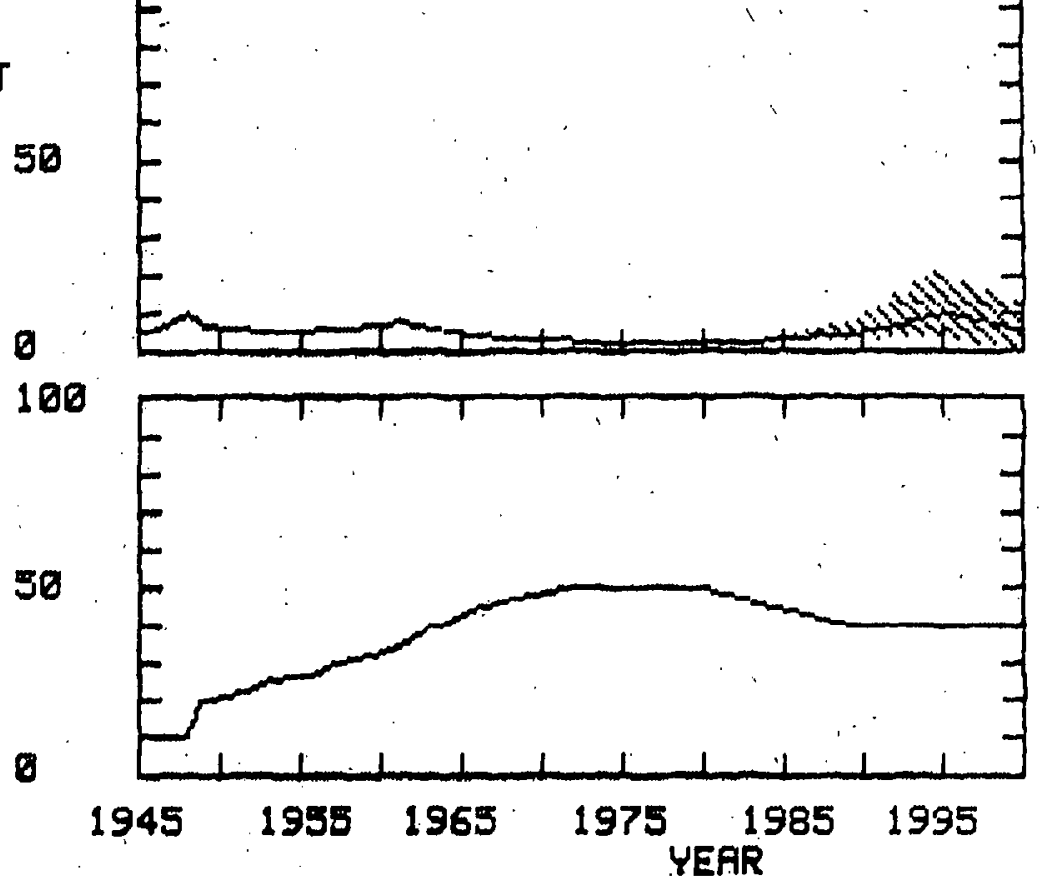

Model result:

SECURITY SFYVRFIGE YEFIRS BETWEEN INCIDENCES DF AIGORESSION)

EDG 5

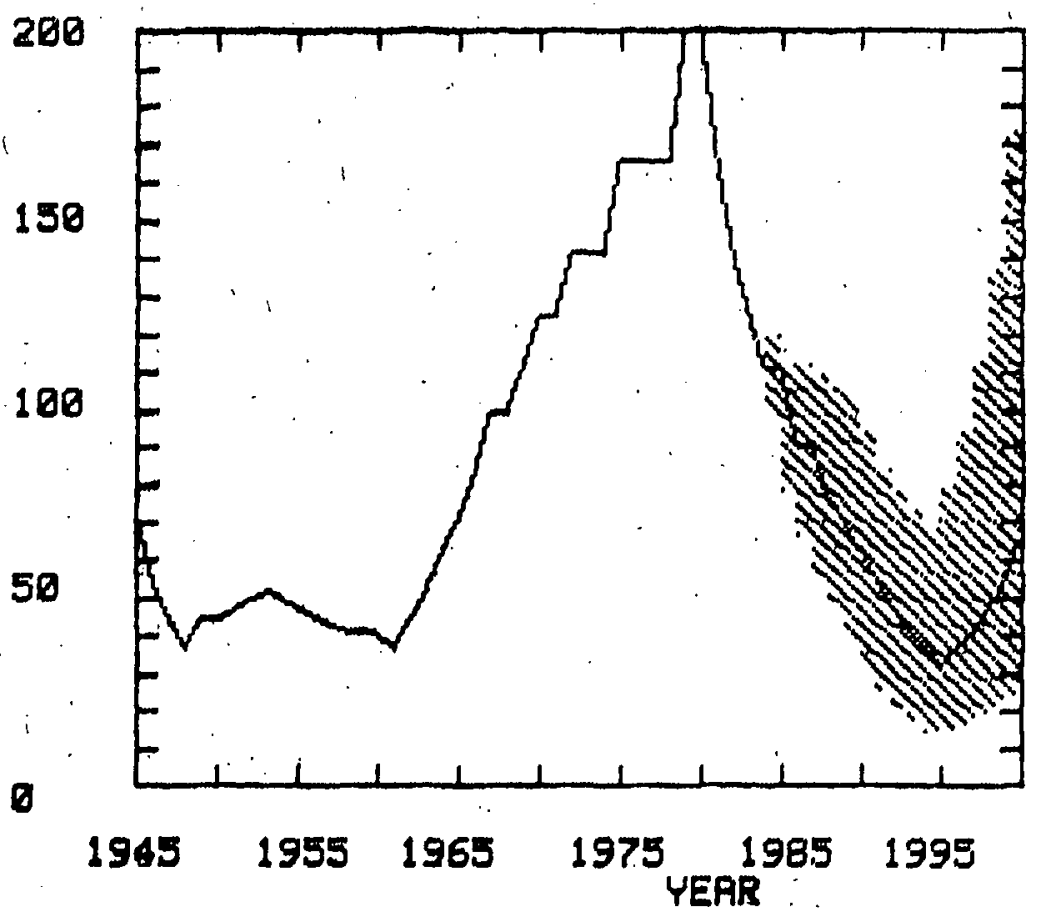




\section{FDREIGH DCEIJPATIDN DF EASTERH EUFGFE}

Data (estimates):

RGGRESSIVE CAFABILITY

OF ENEMYY SPCT. OF THFT

WHICH WOULD FULLY ENEURE

THE AGQRESSIVE OB.JECTIUE)

FGORESSIVE INTENTIONG DF EHEMY SPCT. ESTIMATEI FROBABILITY THAT ENEYY' WILL ATTEMPT RGGRESSION WITHIN ONE MERR I

PFOBABILITY OF SUCCESS IN AVERTINO AN ATTEMPTEI AGGRESSION (FCT.)
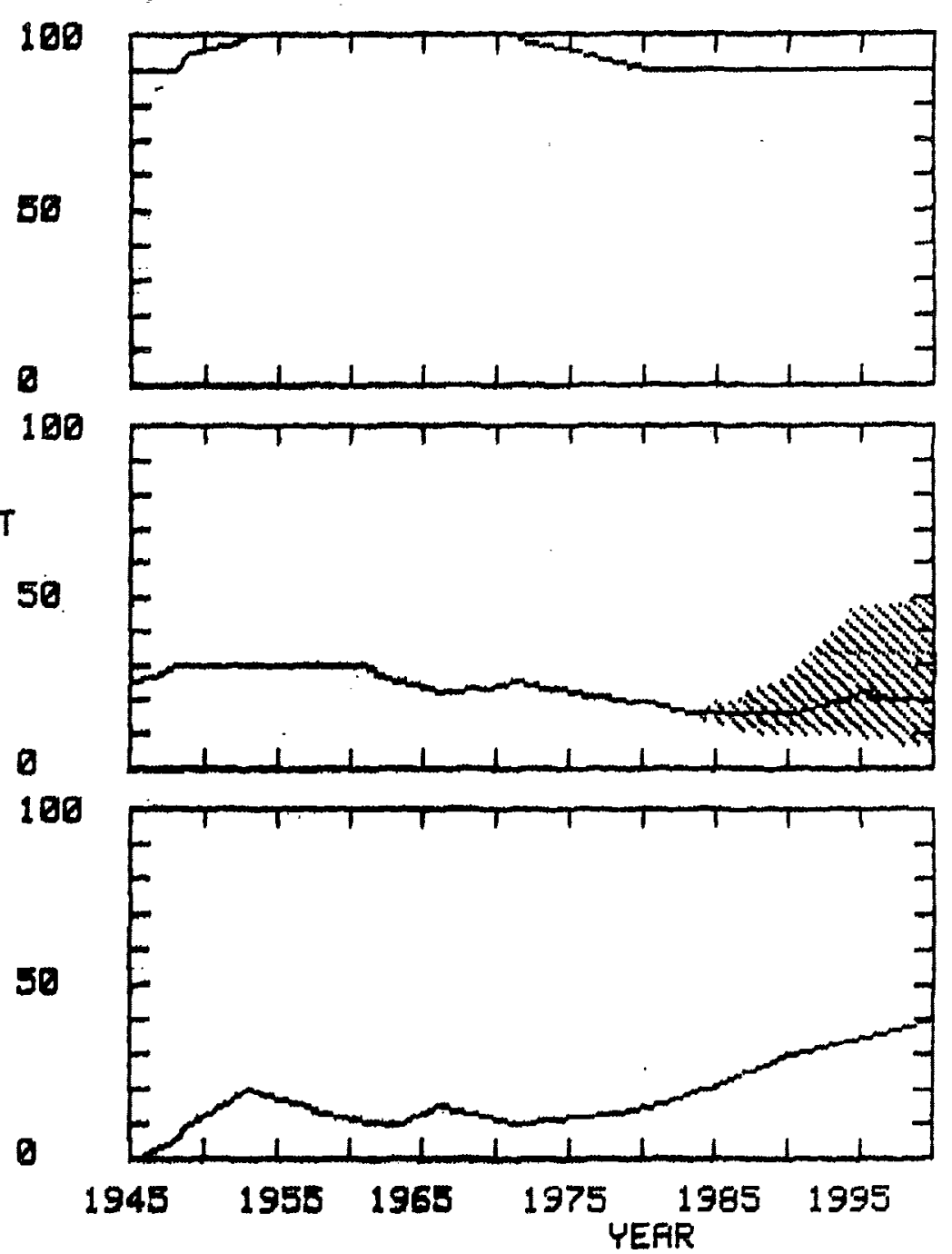

Madel result:

SECURITY SAVERFGE YEARS BETWEEN INCIDEHCES OF FGGRESSIOH)

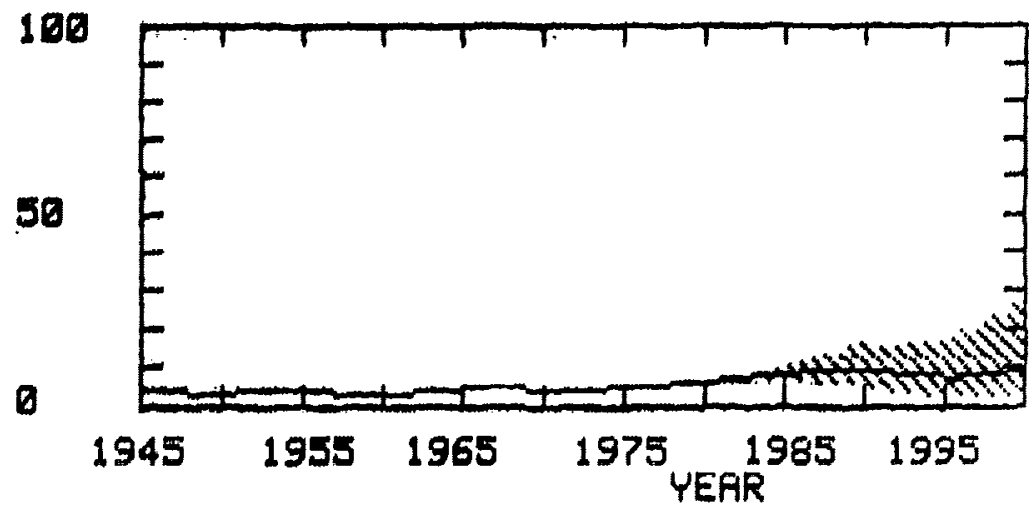


1/78 "TANKER OM EN PRAKSIS" - et matematikprojekt.

Projektrapport af Anne Jensen, Lena Lindenskov, Marianne Kesselhahn og Nicolai Lomholt.

Vejleder: Anders Madsen.

2/78 "OPTIMERING" - Menneskets forøgede beherskelsesmu1 igheder af natur og samfund.

Projektrapport af Tom J. Andersen, Tommy R. Andersen, Gert Kreinøe og Peter H. Lassen.

Vejleder: Bernhelm Booss.

3/78 "OPGAVESAMLING", breddekursus i fysik.

Nr. 3 er a jour fort $i$ marts 1984

Lasse Rasmússen, Aage Bonde Kræmmer, Jens Højgaard Jensen.

4/78 "TRE ESSAYS" - om matematikundervisning, matematiklæreruddannelsen og videnskabsrindalismen.

Mogens Niss.

5/78 "BIBLIOGRAFISK VEJLEDNING til studiet af'DEN MODERNE FYSIIKS HISTORIE".

Helge Kragh.

6/78 "NOGLE ARTIKLER OG DEBATINDLEG OM - læreruddanne1se og undervisning $i$ fysik, og - de naturvidenskabelige fags situation efter studenteroproret".

Karin Beyer, Jens Højgaard Jensen og Bent C. Jørgensen.

7/78 "MATEMATIKKENS FORHOLD TIL SAMFUNDSOKONOMIEN". B.V. Gnedenko.

8/78 "DYNAMIK OG DIAGRAMMER". Introduktion til energy-bound-graph formalismen.

Peder Voetmann Christiansen.

9/78 "OM PRAKSIS' INDF́LYDELSE PA MATEMATIKKENS UDVIKLING". - Motiver til Kepler's: "Nova Stereometria Doliorum Vinarioum".

Projektrapport af Lasse Rasmussen.

Vejleder: Anders Madsen.

10/79 "TERMODYNAMIK I GYMNASIET".

Projektrapport af Jan Christensen og Jeanne Mortensen.

Vejledere: Karin Beyer og Peder Voetmann Christiansen.

$11 / 79$ - "STATISTTISKE MATERIALER"

red. Jorgen Larsen

12/79 "L INEARE DIFFERENTIALL IGNINGER OG DIFFERENT IALLIGNINGSSYSTEMER".

Nr. 12 er udgået

Mogens Brun Heefelt

$13 / 79$ "CAVENDISH'S FORSOG I GYMNASIET". Projektrapport af Gert Kreinoe.

Vejleder: Albert Chr. Paulsen

Nr. 7 er udgået. 
14/79 "BOOKS ABOUT MATHEMATICS: History, Philosophy, Education, Mode 15, System Theory, and Works of Reference etc. A Bibliography".

Else Hoyrup.

15/79 "STRUKTUREL STABILITET OG KATASTROFER $i$ systemer $i$ og udenfor termodynamisk ligevægt".

Specialeopgave af Leif S. Striegler.

Vejleder: Peder Voetmann Christiansen.

16/79 "STATISTIK I KREFTFORSKNINGEN".

Projektrapport af Michael 01sen og Jorn Jensen.

Vejleder: Jargen Larsen.

17/79 "AT SPQRGE OG AT SVARE $i$ fysikundervisningen". Albert Christian Paulsen.

18/79 "MATHEMATICS AND THE REAL WORLD", Proceedings of an International Workshop, Roskilde University Centre, Denmark, 1978. Preprint.

Bernhelm Booss \& Mogens Niss (eds.).

19/79 "GEOMETRI, SKOLE OG VIRKELIGHED".

Projektrapport af Tom J. Andersen, Tommy R. Andersen og Per H.H. Larsen.

Vejleder: Mogens Niss.

20/79 "STATISTISKE MODELLER TIL BESTEMMELSE AF SIKRE DOSER FOR CARCINOGENE STOFFER".

Projektrapport af Michael 01sen og Jorn Jensen.

Vejleder: Jorgen Larsen.

21/79 "KONTROL I GYMNASIET - FORMÅ OG KONSEKVENSER".

Projektrapport af Crilles Bacher, Per S. Jensen, Preben Jensen og Torben Nysteen.

22/79 "SEMIOTIK OG SYSTEMEGENSKABER (1)". 1-port lineart response og støj i fysikken.

Peder Voetmann Christiansen.

23/79 "ON THE HISTORY OF EARLY WAVE MECHANICS - with special emphasis on the role of realitivity". 
29/80 "ODIN - undervisningsmateriale til et kursus $i$

differentialligningsmodeller".

Projektrapport af Tomy R. Andersen, Per H.H. Larsen og Peter H. Lassen.

Vejleder: Mogens Brun Heefelt

30/80 "FUSIONSENERGIEN - - ATOMSAMFUNDETS ENDESTATION". oluf Danieisen.

31/80 "VIDENSKABSTEORETISKE PROBLEMER VED UNDERVISNINGSSY STEMER BASERET PA MENGDELERE".

Projektrapport af Troeis Lange og-Jorgen Karrebak.

Vejleder: Stig Andur Pedersen.

32/80 "POLYMERE STOFFERS VISCOELASTISKE EGENSKABER - BELYST VED HJELP AF MEKANISKE IMPEDANSMALINGER OG MOSSBAUEREFFEKTMAL INGER" .

Projektrapport, speciale, i fysik, af Crilles Bacher og Preben Jensen.

Vejledere: Niels Boye 01 sen og Peder Voetmann Christiansen.

33/80 "KONSTITUERING AF FAG INDEN FOR TEKNISK-NATURVIDENSKABELIGE UDDANNELSER. I-II"

Arne Jakobsen.

34/80 "ENVIRONMENTAL IMPACT OF WIND. ENERGY UTILIZATION". ENERGY SERIES NO.1.

Bent Sorensen.

Nr. 34 er udgået.

Pub1. i "Renewable Sources of-Energy and the Environment", Tycooli International Press, Dublin, 1981:'

$\mathrm{Nr} .30$ er udgået

Udkommer medio 1982 på Fysik-, Matematik- og Kemilærernes forlag.

$\mathrm{Nr} .31$ er p.t. udgảet

35/80 "HISTORISKE STUDIER I DEN NYERE ATOMFYSIKS UDVIKL ING": Helge Kragh.

36/80 "HVAD ER MENINGEN 'MED MATEMATIKUNDERVISNINGEN-?".

Fire artikler.

Mogens Niss.

$37 / 80^{\circ}$ "RENEWABLE ENERGY AND ENERGY STORAGE".

ENERGY SERIES NO.2.

Bent Sorensen.

38/81 "TIL' EN HISTORIETEORI OM NATURERKENDELSE, TEKNOLOGI OG SAMFUND".

Projektrapport af Erik' Gade, Hans Hedal, Henrik Lau og Finn Physant.

Vejledere: Stig Andur Pedersen, Helge Kragh og

Ib-Thiersen.

39/81 "TIL KRITIKKEN AF VEKSTøKONOMIEN".

Jens Hojgaard Jensen.

40/81 "TELEKOMMUNIKATION I DANMARK - oplæg til en teknologivurdering".

Projektrapport af Arne Jorgensen, Bruno Petersen og Jan Vedde.

Vejleder: Per Norgaard.

41/81 "PLANNING AND POLICY CONŚ IDERATIONS RELATED TO THE INTRODUCTION OF RENEWABLE ENERGY SOURCES INTO ENERGY SUPPLY SYSTEMS".

ENERGY SERIES NO.3.

Bent Sorensen.

Nr. 38 er p.t. udgået

Nr. 40 er p.t. udgåt 
42/81 "VIDENSKAB TEORI SAMFUND - En introduktion til materialistiske videnskabsopfattelser".

Helge Kragh og Stig Andur Pedersen.

43/81 1. "COMPARATIVE RISK ASSESSMENT OF TOTAL ENERGY SYSTEMS".

2. "ADVANTAGES AND DISADVANTAGES OF DECENTRALIZATION". ENERGY SERIES NO.4.

Bent Sorensen.

44/81 "HISTORISK UNDERS@GELSE AF DE EKSPERIMENTELLE FORUDSETNINGER FOR RUTHERFORDS ATOMMODEL".

Projektrapport af Niels Thor Nielsen.

Vejleder: Bent $C$. Jorgensen.

46/82 "EKSEMPLARISK UNDERVISNING OG FYSISK ERKENDELSE -

I+II ILLUSTRERET VED TO EKSEMPLER".

Projektrapport af Torben 0 . 0lsen, Lasse Rasmussen og Niels Dreyer Sorensen.

Vejleder: Bent C. Jorgensen.

47/82 "BARSEBACK OG DET VARST OFFICIELT-T®NKELIGE UHELO". ENERGY SERIES NO.5.

Bent Sorensen.

48/82 "EN UNDERSOGELSE AF MATEMATIKUNDERVISNINGEN PA ADGANGSKURSUS TIL. KOBENHAVNS TEKNIKUM".

Projektrapport af Lis Eilertzen, Jorgen Karrebak, Troels Lange, Preben Nerregaard, Lissi Pedersen, Laust Rishøj, Lill Røn, Isac Showiki.

Vejleder: Mogens Niss.

49/82 "ANALYSE AF MULTISPEKTRALE SATELL ITBILLEDER".

Projektrapport af Preben Norregaard.

Vejledere: Jorgen Larsen \& Rasmus 0le Rasmussen.

50/8? "HERSLEV - MILLIGHEDER FOR VEDVARENDE ENERGI I EN I ANII', ISY". INIRCYY "I WII': MII.G.

Rapport af Bent Christensen, Bent Hove Jensen, Dennis B. Møller, Bjarne Laursen, Bjarne Lillethorup og Jacob March Pedersen.

Vejleder: Bent Sørensen.

51/82 "HVAD KAN DER GORES FOR AT AFHJALPE PIGERS BLOKERING OVERFOR MATEMATIK?"

Projektrapport af Lis Eilertzen, Lissi Pedersen, Lill Ron og Susanne Stender.

52/82 "DESUSPENSION OF SPLITTING ELLIPTIC SYMBOLS" Bernhelm Booss \& Krzysztof Wojciechowski.

$53 / 82$ "THE CONSTITUTION OF SUBJECTS IN ENGINEERING EDUCATION".

Arne Jakobsen \& Stig Andur Pedersen.

54/82 "FUTURES RESEARCH" - A Philosophical Analysis of Its Subject-Matter and Methods.

Stig Andur Pedersen \& Johannes Witt-Hansen. 
55/82 "MATEMATISKE MODELLER" - Litteratur på Roskilde Universi tetsbibliotek.

En bibliografi.

Else Hoyrup.

$56 / 82$ - "ENN - TO - MANGE" -

En undersogelse af matematisk okologi.

Projektrapport af Troels Lange.

Vejleder: Anders Madsen.
Vedr. tekst $n r$. 55/82: Se ogsa tekst $62 / 83$.

57/83 "ASPECT EKSPERIMENTET" -

Skjulte variable $i$ kvantemekanikken?

Nr. 57 er udgået.

Projektrapport af Tom Juul Andersen.

Vejleder: Peder Voetmann Christiansen.

58/83 "MATEMATISKE VANDRINGER" - Modelbetragtninger over spredning af dyr mellem smảbiotoper i agerlandet.

Projektrapport af Per Hammershoj Jensen \& Lene Vagn Rasmussen.

Vejleder: Jorgen Larsen.

59/83 "THE METHODOLOGY OF ENERGY PLANNING".

ENERGY SERIES NO. 7.

Bent Sorensen.

60/83 "MATEMATISK MODEKSPERTISE" - et eksempel.

Projektrapport af Erik 0. Gade, Jorgen Karrebæk og Preben Norregaard.

Vejleder: Anders Madsen.

61/83 "FYSIKS IDEOLOGISKE FUNKTION", som et eksempel på en naturvidenskab - historisk set.

Projektrapport af Annette Post Nielsen.

Vejledere: Jens Hoyrup, Jens Højgaard Jensen og Jorgen Vogelius.

.62/83 "MATEMATISKE MODELLER" - Litteratur på Roskilde Universitetsbibliotek.

En bibliografi. 2. rev. udgave

Else Høyrup

63/83 "CREATING ENERGY FUTURES: A SHORT GUIDE TO ENERGY PLANNING" .

ENERGY SERIES No. 8

David Crossley \& Bent Sorensen

64/83 "VON MATHEMATIK UND KRIEG".

Bernhelm Booss og Jens Hoyrup

65/83 "ANVENDT MATEMATIK - TEOṘI ELLER PRAKSIS".

Projektrapport af Per Hedegård Andersen, Kirsten Habekost, Carsten. Holst-Jensen, Annelise von Moos, Else-Marie Pedersen, Erling Moller Pedersen.

Vejledere: Bernhelm Booss \& Klaus Grünbaum

66/83 "MATEMATISKE MODELLER FOR PERIODISK SELEKTION I ESCHERICHIA COLI".

Projektrapport af Hanne. Lisbet Andersen, Dle Richard Jensen og Klavs Frisdahl.

Vejledere: Jorgen Larsen og Anders Hede Madsen 
67/83 "ELIPSOIDE METODEN - EN NY METODE TIL LINEAER PROGRAMMERING?"

Projektrapport af Lone Biilmann og Lars Boye

Vejleder: Mogens Brun Heefelt

68/83 "STOKASTISKE MODELLER I POPULATIONSGENETIK"

- til kritikken af teoriladede modeller.

Projektrapport af Lise Odgård Gade, Susanne Han-

sen, Michael Hviid, Frank Molgård 01 sen.

Vejleder: Jorgen Larsen.

69/83. "ELEVYFORUDSATNINGER I FYSIK"

- en test $\mathrm{i}$ l.g med kommentarer

Albert Chr. Paulsen

70/83 "INDLFRINGS- OG FORMIDLINESPROBLEMER I MATEMATIK PA VOKSENUNDERVISNINGSNIVEAU"

Projektrapport af Hanne Lisbet Andersen, Torben J. Andreasen, Svend Age Houmann, Helle Glerup Jensen, Keld Fl. Nielsen, Lene Vágn Rasmussen.

Vejleder: Klaus Grünbaum \& Anders H. Madsen

$71 / 83$ "PIGER OG FYSIK"

- et problem og en udfordring for skolen?

Karin Beyer, Sussanne Blegaa, Birthe 0lsen, Jette Reich \& Mette Vedelsby

72/83 "VERDEN IFGLGE PEIRCE" - to metafysiske essays, om og af C.S. Peirce.

Peder Voetmann Christiansen

73/83 "EN ENERGIANALYSE AF LANDBRUG" - okologisk contra traditionelt

ENEREY SERIES No. 9

Specialeopgave i fysik af Bent Hove Jensen

Vejleder: Bent Sorensen

74/84 "MINIATURISERING AF MIKROELEKTRONIK" - om videnskabeliggjort teknologi og nytten af at lære fysik

Projektrapport af Bodil Harder og Linda Szkotak Jensen.

Vejledere: Jens Højgaard Jensen og Bent $C$. Jergensen

75/84 "MATEMATIKUNDERVISNINGEN I FREMTIDENS GYMNASIUM" - Case: Linear programmering

Projektrapport af Morten Blomhøj, Klavs Frisdahl, Frank Molgaard 0lsen

Vejledere: Mogens Brun Heefelt \& Jens Bjørneboe

76/84 "KERNEKRAFT I DANMARK?" - Et heringssvar indkaldt af miljoministeriet, med kritik af miljøstyrelsens rapporter af 15. marts 1984.

ENERGY SERIES No. 10

Af Niels Boye 01sen og Bent Sorensen

77/84 "POLITISKE INDEKS - FUP ELLER FAKTA?" Opinionsundersagelser belyst ved statistiske modeller

Projektrapport af Svend Åge Houmann, Keld Nielsen, Susanne Stender

Vejledere:- Jorgen Larsen \& Jens Bjorneboe 
78/84 "JEVNSTROMSLEDNINGSEVNE OG GITTERSTRUKTUR I AMORFT GERMANIUM"

Specialerapport af Hans Hedal, Frank C. Ludvigsen og Finn $C$. Physant

Vejleder: Niels Boye 01sen

79/84 "MATEMATIK OG ALMENDANNELSE"

Projektrapport af Henrik Coster, Mikael Wennerberg Johansen, Povl Kattler, Birgitte Lydholm og Morten Overgaard Nielsen.

Vejleder: Bernhelm Booss

80/84 "KURSUSMATERIALE TIL MATEMATIK B"

Mogens Brun Heefelt

81/84 "FREKVENSAFHENGIG LEDNINGSEVNE I AMORFT GERMANIUM" Specialerapport af Jorgen Wind Petersen og Jan Christensen

Vejleder: Niels Boye 01sen

82/84 "MATEMATIK- OG FYSIKUNDERVISNINGEN I DET AUTOMATISEREDE SAMFUND"

Rapport fra et seminar afholdt $i$ Hvidovre 25-27 april 1983

Red.: Jens Højgaard Jensen, Bent $C$. Jørgensen og Mogens Niss 
ISSN 0106-6242 